NEUROPEPTIDES 52: pp. 19-30. (2015)

\title{
Migraine and neuropeptides
}

János Tajti*, Délia Szok, Zsófia Majláth, Bernadett Tuka, Anett Csáti, László Vécsei

Department of Neurology, University of Szeged, ${ }^{+}$MTA - SZTE Neuroscience Research Group, Szeged, Semmelweis u. 6, H-6725, Szeged Hungary

\section{Affiliation}

János Tajti ${ }^{1 *}$ MD PhD, Délia Szok ${ }^{2}$ MD PhD, Zsófia Majláth ${ }^{3} \mathrm{MD}$, , Bernadett Tuka ${ }^{4+} \mathrm{PhD}$, Anett Csáti ${ }^{5} \mathrm{MD}$ PhD, László Vécsei ${ }^{6+} \mathrm{MD}$ PhD DSc

${ }^{1 *}$ Author for correspondence

Associate Professor of Clinical Neurology,

Department of Neurology, University of Szeged, Semmelweis u. 6, H-6725 Szeged, Hungary Tel.: $+36-62-545348$

Fax: +36-62-545597

E-mail: tajti.janos@med.u-szeged.hu

${ }^{2}$ Associate Professor of Clinical Neurology,

Department of Neurology, University of Szeged, Semmelweis u. 6, H-6725 Szeged, Hungary E-mail: szok.delia@med.u-szeged.hu

${ }^{3}$ Resident in Clinical Neurology,

Department of Neurology, University of Szeged, Semmelweis u. 6, H-6725 Szeged, Hungary E-mail: majlathzsofia@gmail.com

${ }^{4}$ Research Assistant 
MTA - SZTE Neuroscience Research Group, Semmelweis u. 6, H-6725 Szeged, Hungary E-mail: tuka.bernadett@med.u-szeged.hu

${ }^{5}$ Resident in Clinical Neurology,

Department of Neurology, University of Szeged, Semmelweis u. 6, H-6725 Szeged, Hungary

E-mail: csati.anett@gmail.com

${ }^{6}$ Member of the Hungarian Academy of Sciences,

Head of the Department of Neurology,

Department of Neurology, University of Szeged, Semmelweis u. 6, H-6725 Szeged, Hungary

${ }^{+}$MTA - SZTE Neuroscience Research Group, Semmelweis u. 6, H-6725 Szeged, Hungary

E-mail: vecsei.laszlo@med.u-szeged.hu 


\begin{abstract}
Migraine is a common disabling neurovascular primary headache disorder. The pathomechanism is not clear, but extensive preclinical and clinical studies are ongoing. The structural basis of the leading hypothesis is the trigeminovascular system, which includes the trigeminal ganglion, the meningeal vasculature, and the distinct nuclei of the brainstem, the thalamus and the somatosensory cortex.

This review covers the effects of sensory (calcitonin gene-related peptide, pituitary adenylate cyclase-activating polypeptide and substance P), sympathetic (neuropeptide Y) and parasympathetic (vasoactive intestinal peptide) migraine-related neuropeptides and the functions of somatostatin, nociceptin and the orexins in the trigeminovascular system. These neuropeptides may take part in neurogenic inflammation (plasma protein extravasation and vasodilatation) of the intracranial vasculature and peripheral and central sensitization of the trigeminal system.

The results of human clinical studies are discussed with regard to the alterations in these neuropeptides in the plasma, saliva and cerebrospinal fluid during or between migraine attacks, and the therapeutic possibilities involving migraine-related neuropeptides in the acute and prophylactic treatment of migraine headeache are surveyed.
\end{abstract}

Keywords: migraine, neuropeptides, neurogenic inflammation, peripheral and central sensitization, trigeminovascular system 


\section{Graphical abstract}

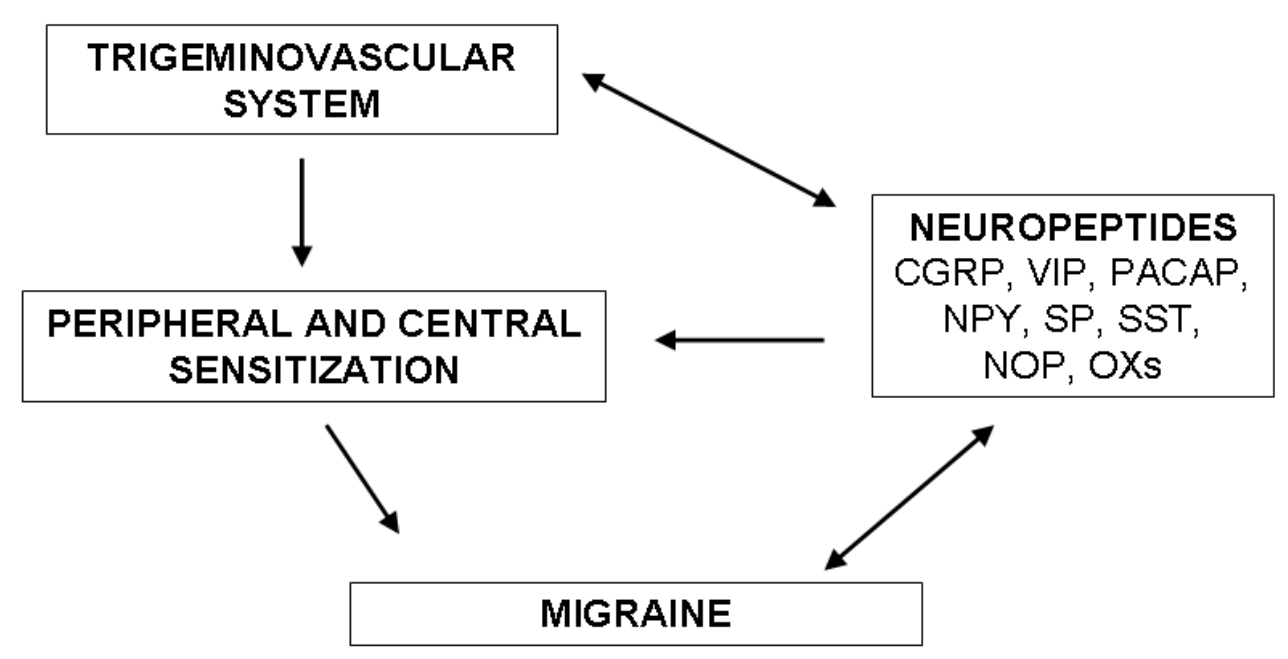




\section{Highlights}

- Although migraine is a highly prevalent neurovascular disease, its exact pathomechanism has not yet been elucidated.

- The leading hypothesis is based on neuropeptide-related modulation of the trigeminovascular system.

- The role played by the neuropeptides in migraine is an active area of preclinical and clinical research.

- Neuropeptides and their receptors might well play a part in the future acute and prophylactic therapy of migraine. 


\section{Introduction}

Migraine is a highly prevalent devastating primary headache disorder that affects around $16 \%$ of the adult population, with a female to male ratio of 3:1. The 1-year prevalence of migraine has been reported to be $10-12 \%$. It is ranked among the top 10 causes of disability worldwide . The two main subtypes of this primary headache syndrome are migraine with and migraine without aura. This pain syndrome is typically characterized by recurrent attacks of unilateral, pulsating headache of moderate or severe intensity, which is aggravated by physical exercise . Migraine-associated symptoms include nausea and/or vomiting, photophobia or phonophobia and allodynia. The aura phenomenon usually precedes the headache; this phase is characterized by the development of transient focal neurological symptoms, the most common being a visual disturbance. In spite of intensive scientific research activities, the exact pathomechanism of migraine remains unknown. Controversies persist concerning the origin of the migraine headache, e.g. vascular or neuronal, cortical or brainstem . Among the several hypotheses relating to migraine, the leading ones are connected with the activation of the trigeminovascular system (TS), the cortical hyperexcitability and the neuronal and glial interactions .

In this review, we focus on the pivotal role of the neuropeptides calcitonin gene-related peptide (CGRP), vasoactive intestinal peptide (VIP), pituitary adenylate-cyclase activating polypeptide (PACAP), neuropeptide Y (NPY), substance P (SP), somatostatin (SST), nociceptin (NOP) and the orexins (OXs) in the modulation of the TS and the other migrainerelated nervous system structures. The alterations in these peptides during migraine attacks or headache-free periods are surveyed, together with the presumed roles of these neuropeptides and their receptors in the acute and prophylactic therapy of migraine. 


\section{CGRP}

CGRP is a 37-amino acid neuropeptide derived from the gene encoding calcitonin on chromosome 11 (Table 1).

The basic function of CGRP in the pathomechanism of migraine was proposed more than two decades ago . Human CGRP has two isoforms: $\alpha$-CGRP and $\beta$-CGRP . $\alpha$-CGRP is widely distributed in the central (CNS) and peripheral nervous systems (PNS) . Most of the cranial vasculature is innervated by $\alpha$-CGRP-containing $\mathrm{C}$ and $\mathrm{A} \delta$ sensory nerve fibres.$\beta$-CGRP, which differs from $\alpha$-CGRP by 3 amino acids, is located in the enteric nerve terminals .

The TS includes the pseudounipolar neurones of the trigeminal ganglia (TRIG). The peripheral branch of these first-order neurones innervates the intracranial meningeal vasculature, while the central nerve endings project to the nociceptive second-order neurones in the trigeminal nucleus caudalis (TNC). The migraine pain-related secondary nociceptive neurones receive convergent synaptic input from the spinal cervical $2(\mathrm{C} 2)$ dorsal root ganglia (DRG) and from the meningeal innervated part of the TRIG. From the second-order neurones, the information is conveyed to the third-order neurones in the thalamus and then to the sensory cortex .

In the mid-1990s, the Weiller group made use of high-resolution positron emission tomography in their elegant demonstration that the blood flow of specific brainstem nuclei, called "migraine generators" (the locus coeruleus - LC, the periaqueductal grey matter - PAG, and the raphe nuclei), and the cerebellum was increased during spontaneous migraine attacks . CGRP is widely expressed in the migraine-related structures such as the TRIG, the TNC and the upper part of the cervical spinal cord and the human LC . A high density of expression of CGRP-receptor components, e.g. the calcitonin receptor-like receptor (CLR) and receptor activity-modifying protein (RAMP)-1, is found in the nerve fibres in the TNC. Recent observations suggest the role of the cerebellum and the CGRP in the modulation of the pain . 
In the TRIG, CGRP is co-expressed with SP, 5-hydroxytryptamine (5-HT), nitric oxide synthase and PACAP. The satellite glia cells (SGCs) of the TRIG express the CLR and RAMP-1 . Recent data point to the pivotal role of the neuronal-glia interaction in the TRIG . The release of CGRP during the neuronal activation of the TRIG stimulates the SGCs, which release proinflammatory cytokines, thereby further modulating the neuronal response . This observation permits a new approach to an understanding of the intraganglionic signalling process.

The CGRP-immunoreactive (-ir) peripheral branch of the neuronal elements of the TRIG supplies mainly the pial arterioles of the cortical surface and the vasculature of the intracranial dura mater . CGRP is a very potent endogenous vasodilatory neuropeptide in the cerebral vasculature . During activation of the TS, CGRP gives rise to neurogenic inflammation (vasodilatation and plasma protein extravasation) in the meningeal vasculature and to mast cell degranulation, this process leading to peripheral sensitization . The clinical manifestation of this peripheral sensitization is the throbbing nature of the migraine headache, while routine physical activity worsens the headache during migraine attacks . In the brainstem, CGRP causes central sensitization of the second-order neurones in the TNC and in the third-order neurones in the thalamus (Figure 1.). This process leads to cephalic and extracephalic allodynia clinically .

An immunohistochemical study revealed CGRP-ir fibres in the vicinity of the neurones of the sphenopalatine ganglia (SPG), and CLR and RAMP-1 immunoreactivity in the SGCs . It is presumed that the sensory system influences the parasympathetic cranial ganglia, e.g. the SPG, during the activation of the TS .

CGRP could act as a biomarker of migraine. Elevated levels of CGRP in the serum in the cranial outflow at the external jugular and cubital vein, and in the saliva, have been detected during spontaneous migraine attacks, and enhanced CGRP plasma levels are observed in 
nitroglycerine (NTG)-induced migraine attacks . Increased CGRP levels have also been measured in the peripheral blood in the cubital vein outside migraine attacks . One research group did not confirm an elevated CGRP level in the external jugular venous blood during migraine without aura attacks . Another research group reported a significant decrease in the CGRP level in the cubital venous plasma during migraine attacks without aura as compared with the level outside the attack period. The differences observed between CGRP levels in plasma obtained from the external jugular and the cubital vein might be explained by the short half-life of the peptide, e.g. a fast degradation within the plasma . The baseline level of CGRP in the saliva has been found to be significantly elevated between attacks in migraine subjects as compared with controls . A clinical study revealed that an increased level of CGRP in the saliva was predictive of responsiveness to a $5-\mathrm{HT}_{1 \mathrm{~B} / 1 \mathrm{D}}$ receptor agonist, rizatriptan . In female migraineurs during NTG-induced migraine attacks the plasma CGRP concentration proved to be decreased in parallel with the headache intensity score after the administration of sumatriptan . An increased CGRP level has been reported in the cerebral spinal fluid (CSF) in chronic migraine subjects as compared with control subjects . Intravenous administration of CGRP caused migraine-like attacks both in migraineurs with aura and in those without aura . In contrast, CGRP infusion did not cause migraine attacks in a rare subgroup of migraineurs, familial hemiplegic migraineurs .

Overall, CGRP may play a crucial role in the neurogenic inflammation and in the peripheral and central sensitization of the TS as concerns the pathomechanism of migraine, and it could be a possible biomarker of migraine headache.

\section{VIP}

VIP, first isolated from the ovine intestine, and consists of 28 amino acids . It belongs in the secretin/glucagon/VIP superfamily of neuropeptides. It acts through the family of seven 
transmembrane $G$ protein-coupled receptors, e.g. vasoactive intestinal polypeptide the receptors 1 and 2 (VPAC1 and VPAC2). VIP is a marker of the parasympathetic nervous system and exerts a strong vasoactive capability influence on the cranio-cervical vasculature . In the early 1990s, a clinical study revealed that the level of VIP in the plasma was elevated during spontaneous migraine attacks in patients who demonstrated symptoms of parasympathetic activation . Peripheral stimulation of the peripheral branch of the neuronal elements of the TRIG (superior sagittal sinus) in the cat revealed a markedly increased level of VIP in external jugular vein blood samples . Immunohistochemical studies later revealed VIP-ir nerve fibres in the "migraine generators", e.g. the nucleus raphe magnus (NRM) and PAG . VIP-ir nerve fibres were not seen in the TNC or at the $\mathrm{C} 1$ and $\mathrm{C} 2$ levels of the spinal cord .

A recent clinical study demonstrated that increased VIP levels were detected in chronic and episodic migraine patients in the attack-free period versus controls . In another study, the VIP levels in the peripheral blood interictally in chronic migraineurs were found to be higher those in control subjects . Administration of onabotulinumtoxin type A is efficacious as treatment for chronic migraine. VIP acts as a potential predictor of onabotulinumtoxin type A responders versus non-responders . During spontaneous migraine attacks, the VIP level was significantly reduced in the external jugular venous blood after rizatriptan administration . In the saliva, the VIP level was significantly elevated interictally in migraine subjects as compared with controls, and following sumatriptan treatment the VIP level was significantly decreased during the migraine attack .

These VIP data suggest that the parasympathetic system may play a role in the initiation of the migraine attack. This statement is supported clinically by the finding that roughly $30 \%$ of migraine patients develop cranial autonomic parasympathetic symptoms such as lacrimation, rhinorrhoea and eyelid oedema. Immunohistological findings have revealed CGRP-ir nerve 
fibres in the SPG, CLR immunoreactivity in the SGCs and RAMP-1 immunoreactivity in the neurones and SGCs in the SPG. These data suggest an interaction between the sensory and parasympathetic systems in the cranial ganglia .

VIP exerts a strong vasodilatatory effect on the craniocervical vasculature . One clinical study revealed that a VIP infusion causes strong dilatation of the superficial temporal artery, but none of the patients reported migraine attacks . It was recently reported that a VIP infusion induced marked dilatation of the extracranial, but not the intracranial arteries in female migraineurs without aura, and only $18 \%$ of the migraine patients experienced migraine-like attacks .

Overall, therefore, VIP is a strong vasodilator with a low capability to induce a migraine attack.

\section{PACAP}

PACAP, a potent stimulator of adenylate cyclase and a biologically active, important neuropeptide, was first isolated from the ovine hypothalamus more than 25 years ago. The gene of PACAP is localized on chromosome 18 . There is a more dominant 38 amino acidcontaining form, PACAP-38, and a C-truncated form, PACAP-27 . These peptides exhibit structural and functional similarities to VIP . Both forms can bind to G-protein-coupled VIP $\left(\mathrm{VPAC}_{1}\right.$ and $\left.\mathrm{VPAC}_{2}\right)$ and specific PACAP $\left(\mathrm{PAC}_{1}\right)$ receptors. PACAP-38 is widely distributed in many organs and is therefore implicated in various biological functions. In human and animal tissues, PACAP and its receptors have been detected in the sensory TRIG and the parasympathetic SPGs and otic ganglia. Moreover, they are closely related to the vascular smooth muscles and are present at different levels of the CNS and PNS. High concentrations of PACAP-38 have been detected among others in the human TNC and the LC, with moderate PACAP expression in the PAG, the raphe nuclei, the thalamus and the 
spinal trigeminal nucleus . PACAP binding sites have been identified in the cortex, the thalamus, the hypothalamus, the brainstem, the TRIG, human mast cells, the middle cerebral arteries (MCAs) and the middle meningeal arteries (MMAs) .

PACAP exerts various peripheral effects and it has a pro-nociceptive role in the CNS . It has functions in neuroinflammation and sensitization. Three synergistic theories (vascular, neuronal and mast cells) have been postulated to underlie the possible effects of PACAP in the mechanisms of migraine. The role of PACAP has been investigated in the NTG-induced animal model of the activated TS. NTG evoked marked migraine-like changes in wild-type mice, but not in PACAP-deficient mice. The systemic administration of PACAP-38 elicited the symptoms of photophobia, elevated the meningeal blood flow and exerted neural activation in the TRIG and TNC in wild-type mice, whereas the corresponding alterations were significantly less pronounced in the lack of the PACAP gene . In another experiment, the administration of NTG generated increases in the levels of PACAP-27 and PACAP-38 immunoreactivity in the TNC in the rat. Similarly, significantly elevated peptide levels were observed in the TNC and also in the extracranial blood flow 90 and 180 min after electrical stimulation of the TRIG in the rat, another model of activated TS . These data suggest that PACAP may elicit peripheral and central sensitization and evoke meningeal vasodilatation. An investigation of the direct vascular effects of PACAP-38 led to the finding that stimulation of the superior sagittal sinus in the cat causes the extracranial release of PACAP . Moreover, a magnetic resonance imaging (MRI) angiographic study revealed that, in contrast with the MCAs PACAP-38-induced headache is associated with significant dilatation of the MMAs, an effect which can be attenuated by the application of sumatriptan . The importance of the $\mathrm{PAC}_{1}$ receptor has been emphasized, but there are results that intradermally injected PACAP38 or VIP can elicit mild, short-lasting cutaneous pain in healthy volunteers, this being mediated primarily by the VPAC receptors . It has additionally been observed that PACAP or 
VIP has lower potency and efficacy in the meningeal vessels than in the coronary arteries, leading to the conclusion that the PACAP-induced migraine-like headache might not involve meningeal vasodilatation. Although, the vascular action of PACAP-38 can not be excluded, it appears likely to be a slight and indirect vasodilator effect. It has been demonstrated clinically that the intravenous administration of PACAP-38 induces delayed migraine-like attacks and vascular alterations in patients with migraine without aura, whereas merely a simple headache occurs in healthy volunteers. A more recent 24-h follow-up study revealed that the infusion of PACAP-38 rather than VIP generates pronounced migraine-like attacks and sustained vasodilatation of the extracranial arteries in migraineurs . Although elevated plasma PACAP-38 concentrations were recorded before the onset of the attacks, changes were not observed in the levels of VIP and tryptase in the blood after the PACAP-38 infusion, which suggests the role of the $\mathrm{PAC}_{1}$ receptors. In another human study, significantly increased PACAP-38 levels were detected in the ictal phase of migraineurs relative to the attack-free period, while significantly lower plasma peptide concentrations were measured in the interictal period of migraineurs as compared with the healthy control group (Figure 2.). A slight negative correlation has been demonstarted between the interictal plasma PACAP-38 level and the disease duration, suggesting that PACAP has vascular effects related to migraine and it can sensitize the trigeminal sensory fibres directly, but the mast cells also have a considerable role in these processes (Figure 3.). It seems that PACAP-38-induced MMA dilatation is probably caused by indirect, phopholipase C-mediated mast cell degranulation, which might be implicated in the mechanisms of migraine .

The experimental and clinical evidence lends support to the mediator role of PACAP in the initiation and/or promotion of migraine attacks . Recognition of the receptorial and signalling mechanisms of PACAP might open up new perspectives for the development of non-peptide, receptor-specific drugs. 


\section{NPY}

NPY, a 36-amino acid peptide, is a marker of the sympathetic nerve endings with long-lasting vasoconstrictor properties, and therefore has a crucial role in the control of the cerebral circulation . In relationship with the craniocervical blood vessels, the sympathetic innervation is supplied by the superior and inferior cervical ganglia and the stellate ganglion. In the sympathetic nerve terminals, NPY is co-stored and co-released with norepinephrine . Immunohistochemical investigations have revealed that one of the distinct brainstem nuclei in humans, the LC, as a "migraine generator", contains the C-terminal flanking peptide of NPY immunoreactivity in the neurones, illustrating their adrenergic nature; the LC sends noradrenergic-containing nerve fibres to the $\mathrm{TNC}$, indicating that the $\mathrm{TNC}$ is influenced by the adrenergic LC .

NPY-ir nerve fibres densely innervate the cerebral dura mater, pial blood vessels and cerebral arteries .

In young migraineurs with aura, the plasma NPY level is increased during attacks, but reduced in the interictal period, suggesting the role of NPY in the pathomechanism of migraine with aura .

After lumbar puncture, the NPY immunoreactivity in the CSF was reported to be higher in migraineurs during the attacks as compared with controls, whereas another research group did not observe a NPY immunoreactivity elevation in the suboccipital CSF or plasma during attacks and attack-free periods of patients with migraine without aura . In migraine patients with or without aura, the NPY immunoreactivity in the external jugular venous blood did not alter during migraine attacks .

In summary, NPY is a good marker of the intracranial sympathetic innervation, but the evidence relating to its potent role in the pathomechanism of migraine pain is not pronounced. 
$\mathrm{SP}$, a member of the tachykinin neuropeptide family, consists of 11 amino acids . Its endogenous receptor is the neurokinin 1 (NK1) receptor. SP is widely expressed in the trigeminal sensory nerve fibres. Dense SP-ir nerve fibres have been observed in the "migraine generators", e.g. the NRM, the LC and the PAG . In the TNC and in the dorsal horns at the spinal C2 level, numerous SP-ir nerve fibres have been detected . SP has a potent function in pain transmission in the different regions of the PNS and the CNS . During activation of the TS, SP induces plasma protein extravasation and vasodilatation in the cerebral dura mater; this is blocked by the selective NK1 receptor antagonists . In the TNC, SP performs nociceptive conduction. The NK1 receptor antagonists also have the ability to inhibit the activation of the second-order neurones in the TNC after electrical stimulation of the TRIG . Preclinical studies have revealed that stimulation of the peripheral branch of the TRIG, e.g. electrical stimulation of the superior sagittal sinus, results in elevations of CGRP and VIP, but not NPY and SP . No elevation of SP in the cranial venous outflow was detected during spontaneous migraine attacks, whereas the salivary SP immunoreactivity was increased during spontaneous migraine attacks without aura versus the level in control subjects . In chronic migraine patients, the plasma and saliva levels of SP were higher than those in control subjects, and associated with pain intensity. The plasma SP concentration was observed to be enhanced in episodic migraineurs during the headache-free periods . In a further study, the SP level in the platelets was higher in migraineurs than in the controls .

Overall, SP has a strong plasma protein extravasation effect, but to date the role of SP in the pathomechanism of migraine has not been fully confirmed. 
SST (previously termed the somatotropin release-inhibiting factor) plays a pivotal role in the regulation of the neuroendocrine system, as an inhibitor of the secretion of growth hormone, thyrotropin-releasing hormone, insulin, glucagon, cholecystokinin, secretin, gastrin, motilin, calcitonin and parathyroid hormone . Its precursor molecule, prepro-SST (116 amino acids), undergoes cleavage to furnish two forms, SST-14 (14 amino acids) and SST-28 (28 amino acids) . The SST-containing neurones are widely distributed in the CNS, e.g. in the cerebral cortex, hippocampus, hypothalamus, brainstem and spinal cord . SST acts on six different SST receptor subtypes belonging in the G-protein-coupled receptor family .

A preclinical animal study has revealed that blockade of the SST receptors by the administration of cyclo-SST to the posterior hypothalamic area of the rat resulted in an antinociceptive effect on the dural electrical and facial thermal inputs in the TNC. In an early clinical study, the SST immunoreactivity in the suboccipital CSF was decreased in migraine patients without aura during the attack-free periods, subsequently further decreasing and reaching statistically significant difference as compared with mixed neuropsychiatric group of patients . CSF obtained by lumbar puncture exhibited a lower SST immunoreactivity level in chronic migraine patients than in controls . In a double-blind parallel group trial, the treatment of migraine attacks with the subcutaneous administration of a long-acting SST analogue (octreotide, SMS 201-995) resulted in a significant reduction of headache pain . In a clinical study involving migraine patients with or without aura, withdrawal of the intravenous infusion of SST did not led to immediate or delayed migraine-like headaches in migraineurs or control subjects .

Overall, further preclinical and clinical investigations are needed to clarify the putative role of SST in the pathomechanism of migraine. 


\section{NOP}

NOP (orphanin FQ), a 17-amino acid opioid-related peptide, is an endogenous ligand for the orphan-like receptor 1, a member of the opioid receptor family (nowadays termed the NOP1 receptor) . The NOP1 receptor is widely distributed in the CNS, e.g. in the hypothalamus, the brainstem and the dorsal horn of the spinal cord. NOP has multidirectional effects in the CNS, exerting algesic, hyperalgesic and analgesic properties, while in the PNS it displays antinociceptive effects . In tracing experiments with immunohistochemical visualization, NOP-ir fibres of trigeminal origin were detected in the dorsal horn of the cervical spinal cord . In the human TRIG, $78 \%$ of medium-sized neurones $(30-60$ um $)$ express NOP immunoreactivity . About $61 \%$ of the NOP-ir neurones are co-localized with CGRP, and $68 \%$ of them contain PACAP . Interestingly, the human intracranial arteries (basilar and MCAs) do not demonstrate NOP1 receptor mRNA expression, and similarly the human extracranial temporal artery does not possess NOP immunoreactivity. NOP does not influence the contractile properties of the human cerebral arteries . The migraine-related CNS structures, such as the TNC, LC, PAG, raphe nuclei, thalamus and sensory cortex, display NOP1 receptor expression. The meningeal vasculature is densely innervated by trigeminal sensory nerve fibres (unmyelinated C-fibres and thinly myelinated $\mathrm{A} \delta$ fibres), and their activation can result in neurogenic inflammation as a source of migraine pain . After electrical stimulation of the MMA, neurogenic dural vasodilatation was observed in an animal model of a closed cranial window . In this experimental set-up, intravenously administered NOP dosedependently suppressed the neurogenic dural vasodilatation via NOP1 receptor activation . A clinical study of the circulating NOP revealed a lower plasma NOP level in migraine patients without aura during the headache-free period than in controls, and the level correlating with the attack frequency . 
Thus, the action of NOP on the NOP1 receptor may play a role in the regulation of the vasomotor response of the cerebral dura mater and may be involved in the modulation of the release of the neuropeptide from the trigeminal sensory nerve terminals.

\section{OXs}

The OXs (also called hypocretins), derived from prepro-OX (130 amino acids), are orexin A (OXA) (33 amino acids) and orexin B (OXB) (28 amino acids) . OXA is selectively bound to the OX1 receptor (OX1R), while both OXA and OXB are bound to the OX2R . OXA and $\mathrm{OXB}$ are exclusively synthesized in the lateral, posterior and paraventricular nuclei of the hypothalamus . OX-containing neurones project to the different nociceptive areas of the brain, e.g. the cerebral cortex, cingulate cortex, paraventricular thalamic nuclei and "migraine generators", e.g. the LC, PAG and NRM . OX1R is selectively expressed in the LC, while $\mathrm{OX} 2 \mathrm{R}$ is expressed in the NRM . A functional imaging $\left(\mathrm{H}_{2}{ }^{15} \mathrm{O}\right.$ positron emission tomography) study demonstrated hypothalamic activation (increased regional cerebral blood flow) during spontaneous migraine attacks without aura .

The OXs have the ability to modulate the TS . The OX-ergic system can attenuate neurogenic dural vasodilatation via OX1R activation, which means inhibition of the TS . On the other hand, the OXs can facilitate the TS via the OX2R. As concerns the OX-containing neurones in the migraine-related structures, this activation is highest during wakefulness and inhibited during sleep. The function of the OXs in sleep is the promotion of waking . Clinical studies have revealed a high level of OXA in the CSF in chronic migraine patients, and mainly in those with medication overuse headache .

The simultaneous antagonism of the OX1R and the OX2R with dual OX receptor antagonist12 (DORA-12) inhibited trigeminal sensory neuronal activation in the TRIG after the injection of complete Freund's adjuvant to the temporomandibular joint in the rat . A recent 
experimental study in rats yielded evidence that DORA-12 resulted in attenuation of the trigeminal nociceptive activity in the TNC after electrical stimulation of the dural trigeminal afferents . However, a randomized double-blind placebo-controlled pilot trial revealed that an OX receptor antagonist (filorexant, $10 \mathrm{mg}$ nightly) failed to provide effectiveness as migraine prophylaxis .

Overall, it emerges that the OX1R and the OX2R may play a role in modulation of the nociceptive transmission in the TS, and the OX-ergic hypothalamic activation may be linked to the pathomechanism of migraine.

\section{Neuropeptide-related migraine therapy}

\section{SP}

The role of NK1 as a receptor of SP has been investigated in preclinical and clinical studies (Table 2).

Under experimental conditions, the NK1 receptor antagonists proved highly potent in blocking plasma protein extravasation and diminishing the firing of second-order neurones in the TNC. However, human clinical studies failed to confirm the efficacy of NK1 receptor antagonists .

Orally administered lanepitant (LY-303,870), an NK1 receptor antagonist has been evaluated for both the acute and the preventive treatment of migraine. A double-blind placebocontrolled cross-over trial demonstrated that lanepitant was not superior to placebo in acute migraine therapy . In a 12-week double-blind study, lanepitant was not effective in preventing attacks of migraine with or without aura .

Another orally administered NK1 receptor antagonist, RPR100893, evaluated in a doubleblind, randomized, placebo-controlled study, proved ineffective in the treatment of acute migraine . 
Likewise, single dose of the intravenously administered vofopitant (GR-205,171) was not effective relative to placebo in the treatment of a single attack of migraine with or without aura . Intravenous infusion of fosaprepitant (L-758,298), a prodrug of the NK1 receptor antagonist L-754,030, did not abort the migraine pain during the headache attack in a double blind study .

To summarize, NK1 receptor antagonists administered either orally or intravenously failed to demonstrate superiority to placebo in either acute or preventive migraine therapy.

\section{CGRP}

For the purpose of the therapy of migraine form the aspect of CGRP, pharmaceutical innovations have been introduced that target the CGRP receptors; these primarily involve the development of antagonists for the acute treatment of migraine and the creation of fully humanized monoclonal antibodies against CGRP itself and the CGRP receptors for the preventive treatment of migraine .

\section{CGRP receptor antagonists}

Small-molecule CGRP receptor antagonists have been developed for clinical use in acute migraine treatment, e.g. olcegepant (BIBN4096BS), telcagepant (MK-0974), MK-3207, MK1602, BMS-694153, BMS-927711 and BI44370TA . Telcagepant has also been evaluated for the prevention of migraine .

Olcegepant and telcagepant have been investigated intensively. Intravenously administered olcegepant was effective relative to placebo for the acute treatment of migraine in a multicentre double-blind randomized study, and telcagepant administered orally for acute migraine therapy was similarly more effective than placebo . A randomized, double-blind, placebo-controlled multicentre trial revealed that telcagepant reduced the number of migraine headache days as compared with placebo in a migraine prophylaxis therapy. Despite the 
favourable effects of the gepants in acute and preventive migraine therapy, in their liver toxicity (elevation of the liver transaminases) limits their widespread clinical use .

\section{CGRP-targeting monoclonal antibodies}

Three monoclonal antibodies (LY2951742, ALD403, and LBR-101) developed that target the CGRP have so far been for the prophylactic treatment of migraine. Besides their effectiveness, the favourable dosing (once or twice per month) promotes the adherence of migraine patients to the treatment. An unfavourable feature is the route of administration, which is subcutaneously or intravenously instead of orally .

Only one monoclonal antibody that targets the CGRP receptor is currently available: AMG 334 . The subcutaneous administration of AMG 334 once per month is undergoing investigation for prevention of the episodic or chronic state of migraine, but clinical data have not yet been published. The data reported to date indicate that fully humanized monoclonal antibodies are promising therapeutic options for migraine prevention.

In summary, neuropeptides may well have a role in the acute and preventive therapy of migraine headache.

\section{Conclusions}

Although migraine dramatically influences the quality of life of the patients, the precise pathomechanism of this type of primary headache disorder is still lacking. The neuropeptides discussed here may have a fundamental role in the processes of meningeal neurogenic inflammation and pain transmission in the TNC, and peripheral and central sensitization of the TS. Animal experimenters in the field of migraine research still face the problem that on appropriate animal migraine model does not yet exist. Moreover, from a clinical aspect in spite of the alterations in these neuropeptides in the different types of migraine (e.g. migraine with or without aura, or episodic or chronic migraine), they have not achieved a function as 
biomarkers. Notably, however, the actual level of any neuropeptide is determined by the rate of biosynthesis and the rate of degradation. Therefore, the measured levels reflect a steady state, from which far-reaching consequences cannot be drawn without the investigation of the turnover. Further preclinical and clinical research is needed for a better understanding of the roles of the neuropeptides in the pathomechanism of migraine headache. These neuropeptides and their receptors could well be valuable targets for the acute and prophylactic treatment of migraine in the near future. 


\section{Abbreviations}

C2: spinal cervical 2;

CGRP: calcitonin gene-related peptide;

CLR: calcitonin receptor-like receptor;

CNS: central nervous system;

CSF: cerebral spinal fluid;

DORA-12: dual orexin receptor antagonist-12;

DRG: dorsal root ganglia;

-ir: -immunoreactive,

LC: locus coeruleus;

MCAs: middle cerebral arteries;

MMAs: middle meningeal arteries;

MRI: magnetic resonance imaging;

NK1: neurokinin 1;

NOP: nociceptin;

NPY: neuropeptide Y;

NRM: nucleus raphe magnus;

NTG: nitroglycerine;

OX1: orexin 1;

OX2: orexin 2;

OXA: orexin A;

OXB: orexin B;

OX: orexin;

PAC1: pituitary adenylate cyclase-activating polypeptide receptor type 1;

PACAP: pituitary adenylate cyclase-activating polypeptide; 
PAG: periaqueductal grey matter;

PNS: peripheral nervous system;

RAMP-1: receptor activity-modifying protein 1;

SGCs: satellite glia cells;

SP: substance P;

SPG: sphenopalatine ganglia;

SST: somatostatin;

TNC: trigeminal nucleus caudalis;

TRIG: trigeminal ganglia;

TS: trigeminovascular system;

VIP: vasoactive intestinal peptide;

VPAC1: vasoactive intestinal polypeptide receptor 1;

VPAC2: vasoactive intestinal polypeptide receptor 2

\section{Conflict of interest}

The authors declare that they have no conflict of interest and have received no payment in the preparation of their manuscript.

\section{Acknowledgements}

This work was supported by the project TÁMOP-4.2.2.A-11/1/KONV-2012-0052, by the Hungarian Brain Research Programme (NAP, Grant No. KTIA_13_NAP-A-III/9.), by EUROHEADPAIN (FP7-Health 2013-Innovation; Grant No. 602633) and by the MTA -

SZTE Neuroscience Research Group of the Hungarian Academy of Sciences and the University of Szeged. 


\section{Figure legends}

Figure 1. Putative mechanism of the activation of trigeminovascular system (modified from refs.

Hypothethically, cortical spreading depression may activate the meningeal nociceptors of trigeminal sensory afferents, resulting in a consequent release of vasoactive neuropeptides (CGRP, SP, PACAP, VIP). These peptides evoke vasodilatation in the meningeal vasculature, plasma protein extravasation and mast cell degranulation, eventually leading to the sensitization of the peripheral nerve branch of the TRIG (peripheral sensitization). This process subsequently leads to the activation and sensitization of the second-order neurones in the TNC and the third-order neurones of the thalamus (central sensitization).

Abbreviations: CSD: cortical spreading depression, CGRP: calcitonin gene-related peptide, PACAP: pituitary adenylate cyclase-activating polypeptide, SP: substance P, TNC: trigeminal nucleus caudalis, TRIG: trigeminal ganglion, VIP: vasoactive intestinal peptide

Figure 2. Alterations in the plasma PACAP-38 concentrations in healthy subjects and migraineurs

The concentration of PACAP-38 may be decreased in the plasma in the interictal period of migraineurs as compared with healthy subjects. It is assumed that brain energy deficit (lactate, magnesium, etc.), mitochondrial disturbances, impairment of blood-brain barrier (matrix metalloproteases, etc.) and neuronal/glial damages may also potentiate the decrease in PACAP-38 levels. Unknown trigger(s) can evoke elevated plasma PACAP-38 level during the attack phase, which can led to vasodilation, mast cell degranulation, neurogenic inflammation, trigeminal activation, contributing the development of sensitization and serious migraine headache. 
Figure 3. PACAP-38-induced alterations in the trigeminovascular system in the ictal period of migraineurs

It is assumed that PACAP-38 can be released from peripheral and central terminals of the primary sensory neurons in the attack phase of migraineurs. PACAP-38 has direct and indirect sensitizing effects (vasodilation, mast cell degranulation, trigeminovascular activation and sensitization) on meningeal vessels and in the area of second-order trigeminal sensory neurons in the brainstem. The peptide may enter the circulatory system and an elevated PACAP-38 level can contribute to the development of migraine headache. 


\section{References}

Abounader, R., Villemure, J.G., Hamel, E., 1995. Characterization of neuropeptide Y (NPY) receptors in human cerebral arteries with selective agonists and the new Y1 antagonist BIBP 3226. Br J Pharmacol. 116, 2245-50.

Akerman, S., Goadsby, P.J., 2009. VPAC1 and PAC1 receptor antagonists inhibit activation of the parasympathetic outflow to the cranial vasculature to prevent autonomic responses and neuronal firing in the trigeminocervical complex. Cephalalgia 29, 130 130.

Alevizaki, M., Shiraishi, A., Rassool, F.V., Ferrier, G.J., MacIntyre, I., Legon, S., 1986. The calcitonin-like sequence of the beta CGRP gene. FEBS Lett. 206, 47-52.

Amin, F.M., Asghar, M.S., Guo, S., Hougaard, A., Hansen, A.E., Schytz, H.W., van der Geest, R.J., de Koning, P.J., Larsson, H.B., Olesen, J., Ashina, M., 2012. Headache and prolonged dilatation of the middle meningeal artery by PACAP38 in healthy volunteers. Cephalalgia. 32, 140-9.

Amin, F.M., Hougaard, A., Schytz, H.W., Asghar, M.S., Lundholm, E., Parvaiz, A.I., de Koning, P.J., Andersen, M.R., Larsson, H.B., Fahrenkrug, J., Olesen, J., Ashina, M., 2014. Investigation of the pathophysiological mechanisms of migraine attacks induced by pituitary adenylate cyclase-activating polypeptide-38. Brain. 137, 779-94.

Arbab, M.A., Wiklund, L., Delgado, T., Svendgaard, N.A., 1988. Stellate ganglion innervation of the vertebro-basilar arterial system demonstrated in the rat with anterograde and retrograde WGA-HRP tracing. Brain Res. 445, 175-80.

Arimura, A., 1992. Pituitary adenylate cyclase activating polypeptide (PACAP): discovery and current status of research. Regul Pept. 37, 287-303.

Arimura, A., 2007. PACAP: the road to discovery. Peptides. 28, 1617-9.

Ashina, M., Bendtsen, L., Jensen, R., Schifter, S., Olesen, J., 2000. Evidence for increased plasma levels of calcitonin gene-related peptide in migraine outside of attacks. Pain. 86, 133-8.

Avnon, Y., Nitzan, M., Sprecher, E., Rogowski, Z., Yarnitsky, D., 2003. Different patterns of parasympathetic activation in uni- and bilateral migraineurs. Brain. 126, 1660-70.

Avnon, Y., Nitzan, M., Sprecher, E., Rogowski, Z., Yarnitsky, D., 2004. Autonomic asymmetry in migraine: augmented parasympathetic activation in left unilateral migraineurs. Brain. 127, 2099-108.

Barbanti, P., Fabbrini, G., Pesare, M., Vanacore, N., Cerbo, R., 2002. Unilateral cranial autonomic symptoms in migraine. Cephalalgia. 22, 256-9.

Bartsch, T., Akerman, S., Goadsby, P.J., 2002. The ORL-1 (NOP1) receptor ligand nociceptin/orphanin FQ (N/OFQ) inhibits neurogenic dural vasodilatation in the rat. Neuropharmacology. 43, 991-8.

Bartsch, T., Levy, M.J., Knight, Y.E., Goadsby, P.J., 2004. Differential modulation of nociceptive dural input to [hypocretin] orexin $\mathrm{A}$ and $\mathrm{B}$ receptor activation in the posterior hypothalamic area. Pain. 109, 367-78.

Bartsch, T., Levy, M.J., Knight, Y.E., Goadsby, P.J., 2005. Inhibition of nociceptive dural input in the trigeminal nucleus caudalis by somatostatin receptor blockade in the posterior hypothalamus. Pain. 117, 30-9.

Baun, M., Hay-Schmidt, A., Edvinsson, L., Olesen, J., Jansen-Olesen, I., 2011. Pharmacological characterization and expression of VIP and PACAP receptors in isolated cranial arteries of the rat. Eur J Pharmacol. 670, 186-94. 
Baun, M., Pedersen, M.H., Olesen, J., Jansen-Olesen, I., 2012. Dural mast cell degranulation is a putative mechanism for headache induced by PACAP-38. Cephalalgia. 32, 33745.

Beattie, D.T., Connor, H.E., Hagan, R.M., 1995. Recent developments in tachykinin NK1 receptor antagonists: prospects for the treatment of migraine headache. Can J Physiol Pharmacol. 73, 871-7.

Bellamy, J.L., Cady, R.K., Durham, P.L., 2006. Salivary levels of CGRP and VIP in rhinosinusitis and migraine patients. Headache. 46, 24-33.

Bersani, M., Thim, L., Baldissera, F.G., Holst, J.J., 1989. Prosomatostatin 1-64 is a major product of somatostatin gene expression in pancreas and gut. J Biol Chem. 264, 10633-6.

Bhatt, D.K., Gupta, S., Olesen, J., Jansen-Olesen, I., 2014. PACAP-38 infusion causes sustained vasodilation of the middle meningeal artery in the rat: possible involvement of mast cells. Cephalalgia. 34, 877-86.

Bigal, M.E., Walter, S., Rapoport, A.M., 2013. Calcitonin gene-related peptide (CGRP) and migraine current understanding and state of development. Headache. 53, 1230-44.

Bigal, M.E., Walter, S., 2014. Monoclonal antibodies for migraine: preventing calcitonin gene-related peptide activity. CNS Drugs. 28, 389-99.

Bigal, M.E., Walter, S., Bronson, M., Alibhoy, A., Escandon, R., 2014. Cardiovascular and hemodynamic parameters in women following prolonged CGRP inhibition using LBR-101, a monoclonal antibody against CGRP. Cephalalgia. 34, 968-76.

Brazeau, P., Vale, W., Burgus, R., Ling, N., Butcher, M., Rivier, J., Guillemin, R., 1973. Hypothalamic polypeptide that inhibits the secretion of immunoreactive pituitary growth hormone. Science. 179, 77-9.

Bridge, K.E., Wainwright, A., Reilly, K., Oliver, K.R., 2003. Autoradiographic localization of (125)i[Tyr(14)] nociceptin/orphanin FQ binding sites in macaque primate CNS. Neuroscience. 118, 513-23.

Burdakov, D., Alexopoulos, H., 2005. Metabolic state signalling through central hypocretin/orexin neurons. J Cell Mol Med. 9, 795-803.

Burstein, R., Yarnitsky, D., Goor-Aryeh, I., Ransil, B.J., Bajwa, Z.H., 2000. An association between migraine and cutaneous allodynia. Ann Neurol. 47, 614-24.

Buzzi, M.G., Moskowitz, M.A., 1992. The trigemino-vascular system and migraine. Pathol Biol (Paris). 40, 313-7.

Cady, R.J., Denson, J.E., Sullivan, L.Q., Durham, P.L., 2014. Dual orexin receptor antagonist 12 inhibits expression of proteins in neurons and glia implicated in peripheral and central sensitization. Neuroscience. 269, 79-92.

Cady, R.K., Vause, C.V., Ho, T.W., Bigal, M.E., Durham, P.L., 2009. Elevated saliva calcitonin gene-related peptide levels during acute migraine predict therapeutic response to rizatriptan. Headache. 49, 1258-66.

Cernuda-Morollon, E., Larrosa, D., Ramon, C., Vega, J., Martinez-Camblor, P., Pascual, J., 2013. Interictal increase of CGRP levels in peripheral blood as a biomarker for chronic migraine. Neurology. 81, 1191-6.

Cernuda-Morollon, E., Martinez-Camblor, P., Ramon, C., Larrosa, D., Serrano-Pertierra, E., Pascual, J., 2014. CGRP and VIP levels as predictors of efficacy of Onabotulinumtoxin type A in chronic migraine. Headache. 54, 987-95.

Chabi, A., Zhang, Y., Jackson, S., Cady, R., Lines, C., Herring, W.J., Connor, K.M., Michelson, D., 2014. Randomized controlled trial of the orexin receptor antagonist filorexant for migraine prophylaxis. Cephalalgia.

Chan, K.Y., Baun, M., de Vries, R., van den Bogaerdt, A.J., Dirven, C.M., Danser, A.H., Jansen-Olesen, I., Olesen, J., Villalon, C.M., MaassenVanDenBrink, A., Gupta, S., 
2011. Pharmacological characterization of VIP and PACAP receptors in the human meningeal and coronary artery. Cephalalgia. 31, 181-9.

Chang, M.M., Leeman, S.E., Niall, H.D., 1971. Amino-acid sequence of substance P. Nat New Biol. 232, 86-7.

Chaudhary, P., Baumann, T.K., 2002. Expression of VPAC2 receptor and PAC1 receptor splice variants in the trigeminal ganglion of the adult rat. Brain Res Mol Brain Res. 104, 137-42.

Couvineau, A., Laburthe, M., 2012. VPAC receptors: structure, molecular pharmacology and interaction with accessory proteins. Br J Pharmacol. 166, 42-50.

Csati, A., Tajti, J., Kuris, A., Tuka, B., Edvinsson, L., Warfvinge, K., 2012a. Distribution of vasoactive intestinal peptide, pituitary adenylate cyclase-activating peptide, nitric oxide synthase, and their receptors in human and rat sphenopalatine ganglion. Neuroscience. 202, 158-68.

Csati, A., Tajti, J., Tuka, B., Edvinsson, L., Warfvinge, K., 2012b. Calcitonin gene-related peptide and its receptor components in the human sphenopalatine ganglion -interaction with the sensory system. Brain Res. 1435, 29-39.

De Potter, W.P., Kurzawa, R., Miserez, B., Coen, E.P., 1995. Evidence against differential release of noradrenaline, neuropeptide $\mathrm{Y}$, and dopamine-beta-hydroxylase from adrenergic nerves in the isolated perfused sheep spleen. Synapse. 19, 67-76.

Denuelle, M., Fabre, N., Payoux, P., Chollet, F., Geraud, G., 2007. Hypothalamic activation in spontaneous migraine attacks. Headache. 47, 1418-26.

Dickson, L., Finlayson, K., 2009. VPAC and PAC receptors: From ligands to function. Pharmacol Ther. 121, 294-316.

Diener, H.C., Group, R.P.R.S., 2003. RPR100893, a substance-P antagonist, is not effective in the treatment of migraine attacks. Cephalalgia. 23, 183-5.

Dodick, D.W., Turkel, C.C., DeGryse, R.E., Aurora, S.K., Silberstein, S.D., Lipton, R.B., Diener, H.C., Brin, M.F., Group, P.C.M.S., 2010. OnabotulinumtoxinA for treatment of chronic migraine: pooled results from the double-blind, randomized, placebocontrolled phases of the PREEMPT clinical program. Headache. 50, 921-36.

Durham, P., Papapetropoulos, S., 2013. Biomarkers associated with migraine and their potential role in migraine management. Headache. 53, 1262-77.

Edvinsson, L., Copeland, J.R., Emson, P.C., McCulloch, J., Uddman, R., 1987. Nerve fibers containing neuropeptide $\mathrm{Y}$ in the cerebrovascular bed: immunocytochemistry, radioimmunoassay, and vasomotor effects. J Cereb Blood Flow Metab. 7, 45-57.

Edvinsson, L., 1991. Innervation and effects of dilatory neuropeptides on cerebral vessels. New aspects. Blood Vessels. 28, 35-45.

Edvinsson, L., Jansen, I., Cunha e Sa, M., Gulbenkian, S., 1994. Demonstration of neuropeptide containing nerves and vasomotor responses to perivascular peptides in human cerebral arteries. Cephalalgia. 14, 88-96.

Edvinsson, L., Goadsby, P.J., 1995. Neuropeptides in the cerebral circulation: relevance to headache. Cephalalgia. 15, 272-6.

Edvinsson, L., Goadsby, P.J., 1998. Neuropeptides in headache. Eur J Neurol. 5, 329-341.

Edvinsson, L., Elsas, T., Suzuki, N., Shimizu, T., Lee, T.J., 2001. Origin and Co-localization of nitric oxide synthase, CGRP, PACAP, and VIP in the cerebral circulation of the rat. Microsc Res Tech. 53, 221-8.

Edvinsson, L., Uddman, R., 2005. Neurobiology in primary headaches. Brain Res Brain Res Rev. 48, 438-56.

Edvinsson, L., Eftekhari, S., Salvatore, C.A., Warfvinge, K., 2011. Cerebellar distribution of calcitonin gene-related peptide (CGRP) and its receptor components calcitonin 
receptor-like receptor (CLR) and receptor activity modifying protein 1 (RAMP1) in rat. Mol Cell Neurosci. 46, 333-9.

Edvinsson, L., Villalon, C.M., MaassenVanDenBrink, A., 2012. Basic mechanisms of migraine and its acute treatment. Pharmacol Ther. 136, 319-33.

Eftekhari, S., Salvatore, C.A., Calamari, A., Kane, S.A., Tajti, J., Edvinsson, L., 2010. Differential distribution of calcitonin gene-related peptide and its receptor components in the human trigeminal ganglion. Neuroscience. 169, 683-96.

Eftekhari, S., Edvinsson, L., 2011. Calcitonin gene-related peptide (CGRP) and its receptor components in human and rat spinal trigeminal nucleus and spinal cord at C1-level. BMC Neurosci. 12, 112.

Eftekhari, S., Salvatore, C.A., Gaspar, R.C., Roberts, R., O'Malley, S., Zeng, Z., Edvinsson, L., 2013. Localization of CGRP receptor components, CGRP, and receptor binding sites in human and rhesus cerebellar cortex. Cerebellum. 12, 937-49.

Eftekhari, S., Salvatore, C.A., Johansson, S., Chen, T.B., Zeng, Z., Edvinsson, L., 2014. Localization of CGRP, CGRP receptor, PACAP and glutamate in trigeminal ganglion. Relation to the blood-brain barrier. Brain Res.

Emeson, R.B., Hedjran, F., Yeakley, J.M., Guise, J.W., Rosenfeld, M.G., 1989. Alternative production of calcitonin and CGRP mRNA is regulated at the calcitonin-specific splice acceptor. Nature. 341, 76-80.

Erdling, A., Sheykhzade, M., Maddahi, A., Bari, F., Edvinsson, L., 2013. VIP/PACAP receptors in cerebral arteries of rat: characterization, localization and relation to intracellular calcium. Neuropeptides. 47, 85-92.

Ertsey, C., Hantos, M., Bozsik, G., Tekes, K., 2005. Plasma nociceptin levels are reduced in migraine without aura. Cephalalgia. 25, 261-6.

Furst, S., 1999. Transmitters involved in antinociception in the spinal cord. Brain Res Bull. 48, 129-41.

Fusayasu, E., Kowa, H., Takeshima, T., Nakaso, K., Nakashima, K., 2007. Increased plasma substance $\mathrm{P}$ and CGRP levels, and high ACE activity in migraineurs during headachefree periods. Pain. 128, 209-14.

Gallai, V., Sarchielli, P., Trequattrini, A., Paciaroni, M., Usai, F., Palumbo, R., 1994. Neuropeptide $Y$ in juvenile migraine and tension-type headache. Headache. 34, 35-40.

Gerard, N.P., Garraway, L.A., Eddy, R.L., Jr., Shows, T.B., Iijima, H., Paquet, J.L., Gerard, C., 1991. Human substance P receptor (NK-1): organization of the gene, chromosome localization, and functional expression of cDNA clones. Biochemistry. 30, 10640-6.

Giuliani, S., Lecci, A., Maggi, C.A., 2000. Nociceptin and neurotransmitter release in the periphery. Peptides. 21, 977-84.

Goadsby, P.J., Edvinsson, L., Ekman, R., 1990. Vasoactive peptide release in the extracerebral circulation of humans during migraine headache. Ann Neurol. 28, 183-7.

Goadsby, P.J., Edvinsson, L., 1993. Examination of the involvement of neuropeptide Y (NPY) in cerebral autoregulation using the novel NPY antagonist PP56. Neuropeptides. 24, 27-33.

Goadsby, P.J., 2005. Migraine, allodynia, sensitisation and all of that. Eur Neurol. 53 Suppl 1, $10-6$.

Goadsby, P.J., 2013. Autonomic nervous system control of the cerebral circulation. Handb Clin Neurol. 117, 193-201.

Goldstein, D.J., Wang, O., Saper, J.R., Stoltz, R., Silberstein, S.D., Mathew, N.T., 1997. Ineffectiveness of neurokinin-1 antagonist in acute migraine: a crossover study. Cephalalgia. 17, 785-90. 
Goldstein, D.J., Offen, W.W., Klein, E.G., Phebus, L.A., Hipskind, P., Johnson, K.W., Ryan, R.E., Jr., 2001. Lanepitant, an NK-1 antagonist, in migraine prevention. Cephalalgia. 21, 102-6.

Gotter, A.L., Roecker, A.J., Hargreaves, R., Coleman, P.J., Winrow, C.J., Renger, J.J., 2012. Orexin receptors as therapeutic drug targets. Prog Brain Res. 198, 163-88.

Gupta, R., Bhatia, M.S., 2007. A report of cranial autonomic symptoms in migraineurs. Cephalalgia. 27, 22-8.

Hannibal, J., 2002. Pituitary adenylate cyclase-activating peptide in the rat central nervous system: an immunohistochemical and in situ hybridization study. J Comp Neurol. 453, 389-417.

Hannon, J.P., Nunn, C., Stolz, B., Bruns, C., Weckbecker, G., Lewis, I., Troxler, T., Hurth, K., Hoyer, D., 2002. Drug design at peptide receptors: somatostatin receptor ligands. J Mol Neurosci. 18, 15-27.

Hansen, J.M., Hauge, A.W., Olesen, J., Ashina, M., 2010. Calcitonin gene-related peptide triggers migraine-like attacks in patients with migraine with aura. Cephalalgia. 30, 1179-86.

Hansen, J.M., Thomsen, L.L., Olesen, J., Ashina, M., 2011. Calcitonin gene-related peptide does not cause migraine attacks in patients with familial hemiplegic migraine. Headache. 51, 544-53.

Headache Classification Committee of the International Headache, S., 2013. The International Classification of Headache Disorders, 3rd edition (beta version). Cephalalgia. 33, 629808.

Helyes, Z., Pozsgai, G., Borzsei, R., Nemeth, J., Bagoly, T., Mark, L., Pinter, E., Toth, G., Elekes, K., Szolcsanyi, J., Reglodi, D., 2007. Inhibitory effect of PACAP-38 on acute neurogenic and non-neurogenic inflammatory processes in the rat. Peptides. 28, 184755.

Ho, T.W., Mannix, L.K., Fan, X., Assaid, C., Furtek, C., Jones, C.J., Lines, C.R., Rapoport, A.M., group, M.K.P.s., 2008. Randomized controlled trial of an oral CGRP receptor antagonist, MK-0974, in acute treatment of migraine. Neurology. 70, 1304-12.

Ho, T.W., Edvinsson, L., Goadsby, P.J., 2010. CGRP and its receptors provide new insights into migraine pathophysiology. Nat Rev Neurol. 6, 573-82.

Ho, T.W., Connor, K.M., Zhang, Y., Pearlman, E., Koppenhaver, J., Fan, X., Lines, C., Edvinsson, L., Goadsby, P.J., Michelson, D., 2014. Randomized controlled trial of the CGRP receptor antagonist telcagepant for migraine prevention. Neurology. 83, 95866.

Hoffmann, J., Supronsinchai, W., Akerman, S., Andreou, A.P., Winrow, C.J., Renger, J., Hargreaves, R., Goadsby, P.J., 2014. Evidence for orexinergic mechanisms in migraine. Neurobiol Dis. 74C, 137-143.

Holland, P., Goadsby, P.J., 2007. The hypothalamic orexinergic system: pain and primary headaches. Headache. 47, 951-62.

Holland, P.R., Akerman, S., Goadsby, P.J., 2005. Orexin 1 receptor activation attenuates neurogenic dural vasodilation in an animal model of trigeminovascular nociception. $\mathrm{J}$ Pharmacol Exp Ther. 315, 1380-5.

Holland, P.R., Akerman, S., Goadsby, P.J., 2006. Modulation of nociceptive dural input to the trigeminal nucleus caudalis via activation of the orexin 1 receptor in the rat. Eur $\mathrm{J}$ Neurosci. 24, 2825-33.

Holland, P.R., 2014. Headache and sleep: shared pathophysiological mechanisms. Cephalalgia. 34, 725-44. 
Hou, M., Kanje, M., Longmore, J., Tajti, J., Uddman, R., Edvinsson, L., 2001. 5-HT(1B) and 5-HT(1D) receptors in the human trigeminal ganglion: co-localization with calcitonin gene-related peptide, substance P and nitric oxide synthase. Brain Res. 909, 112-20.

Hou, M., Uddman, R., Tajti, J., Edvinsson, L., 2003. Nociceptin immunoreactivity and receptor mRNA in the human trigeminal ganglion. Brain Res. 964, 179-86.

Jang, M.U., Park, J.W., Kho, H.S., Chung, S.C., Chung, J.W., 2011. Plasma and saliva levels of nerve growth factor and neuropeptides in chronic migraine patients. Oral Dis. 17, 187-93.

Johansson, O., Hokfelt, T., Elde, R.P., 1984. Immunohistochemical distribution of somatostatin-like immunoreactivity in the central nervous system of the adult rat. Neuroscience. 13, 265-339.

Juhasz, G., Zsombok, T., Jakab, B., Nemeth, J., Szolcsanyi, J., Bagdy, G., 2005. Sumatriptan causes parallel decrease in plasma calcitonin gene-related peptide (CGRP) concentration and migraine headache during nitroglycerin induced migraine attack. Cephalalgia. 25, 179-83.

Kapicioglu, S., Gokce, E., Kapicioglu, Z., Ovali, E., 1997. Treatment of migraine attacks with a long-acting somatostatin analogue (octreotide, SMS 201-995). Cephalalgia. 17, 2730 .

Keller, J.T., Marfurt, C.F., 1991. Peptidergic and serotoninergic innervation of the rat dura mater. J Comp Neurol. 309, 515-34.

Kim, H.Y., Hong, E., Kim, J.I., Lee, W., 2004. Solution structure of human orexin-A: regulator of appetite and wakefulness. J Biochem Mol Biol. 37, 565-73.

Kimura, C., Ohkubo, S., Ogi, K., Hosoya, M., Itoh, Y., Onda, H., Miyata, A., Jiang, L., Dahl, R.R., Stibbs, H.H., et al., 1990. A novel peptide which stimulates adenylate cyclase: molecular cloning and characterization of the ovine and human cDNAs. Biochem Biophys Res Commun. 166, 81-9.

Knutsson, M., Edvinsson, L., 2002. Distribution of mRNA for VIP and PACAP receptors in human cerebral arteries and cranial ganglia. Neuroreport. 13, 507-9.

Kovács, K., Kapócs, G., Widerlöv, E., Ekman, R., Vécsei, L., Jelencsik, I., Csanda, E., 1991. Suboccipital cerebrospinal fluid and plasma concentrations of corticotropin-releasings hormone and calcitonin gene-related peptide in patients with common migraine. Nordic Journal of Psychiatry. 45, 11-16.

Koves, K., Arimura, A., Gorcs, T.G., Somogyvari-Vigh, A., 1991. Comparative distribution of immunoreactive pituitary adenylate cyclase activating polypeptide and vasoactive intestinal polypeptide in rat forebrain. Neuroendocrinology. 54, 159-69.

Koves, K., Gorcs, T.J., Kausz, M., Arimura, A., 1994. Present status of knowledge about the distribution and colocalization of PACAP in the forebrain. Acta Biol Hung. 45, 297321.

Kulka, M., Sheen, C.H., Tancowny, B.P., Grammer, L.C., Schleimer, R.P., 2008. Neuropeptides activate human mast cell degranulation and chemokine production. Immunology. 123, 398-410.

Laburthe, M., Couvineau, A., Tan, V., 2007. Class II G protein-coupled receptors for VIP and PACAP: structure, models of activation and pharmacology. Peptides. 28, 1631-9.

Lassen, L.H., Haderslev, P.A., Jacobsen, V.B., Iversen, H.K., Sperling, B., Olesen, J., 2002. CGRP may play a causative role in migraine. Cephalalgia. 22, 54-61.

Lee, J.H., Bang, E., Chae, K.J., Kim, J.Y., Lee, D.W., Lee, W., 1999. Solution structure of a new hypothalamic neuropeptide, human hypocretin-2/orexin-B. Eur J Biochem. 266, 831-9. 
Legradi, G., Shioda, S., Arimura, A., 1994. Pituitary adenylate cyclase-activating polypeptide-like immunoreactivity in autonomic regulatory areas of the rat medulla oblongata. Neurosci Lett. 176, 193-6.

Lennerz, J.K., Ruhle, V., Ceppa, E.P., Neuhuber, W.L., Bunnett, N.W., Grady, E.F., Messlinger, K., 2008. Calcitonin receptor-like receptor (CLR), receptor activitymodifying protein 1 (RAMP1), and calcitonin gene-related peptide (CGRP) immunoreactivity in the rat trigeminovascular system: differences between peripheral and central CGRP receptor distribution. J Comp Neurol. 507, 1277-99.

Levy, M.J., Matharu, M.S., Bhola, R., Lightman, S., Goadsby, P.J., 2003. Somatostatin infusion withdrawal: a study of patients with migraine, cluster headache and healthy volunteers. Pain. 102, 235-41.

Lipton, R.B., Stewart, W.F., Diamond, S., Diamond, M.L., Reed, M., 2001. Prevalence and burden of migraine in the United States: data from the American Migraine Study II. Headache. 41, 646-57.

Marfurt, C.F., Del Toro, D.R., 1987. Corneal sensory pathway in the rat: a horseradish peroxidase tracing study. J Comp Neurol. 261, 450-9.

Markovics, A., Kormos, V., Gaszner, B., Lashgarara, A., Szoke, E., Sandor, K., Szabadfi, K., Tuka, B., Tajti, J., Szolcsanyi, J., Pinter, E., Hashimoto, H., Kun, J., Reglodi, D., Helyes, Z., 2012. Pituitary adenylate cyclase-activating polypeptide plays a key role in nitroglycerol-induced trigeminovascular activation in mice. Neurobiol Dis. 45, 63344.

May, A., Goadsby, P.J., 2001. Substance P receptor antagonists in the therapy of migraine. Expert Opin Investig Drugs. 10, 673-8.

Messlinger, K., Fischer, M.J., Lennerz, J.K., 2011. Neuropeptide effects in the trigeminal system: pathophysiology and clinical relevance in migraine. Keio J Med. 60, 82-9.

Meunier, J., Mouledous, L., Topham, C.M., 2000. The nociceptin (ORL1) receptor: molecular cloning and functional architecture. Peptides. 21, 893-900.

Meunier, J.C., Mollereau, C., Toll, L., Suaudeau, C., Moisand, C., Alvinerie, P., Butour, J.L., Guillemot, J.C., Ferrara, P., Monsarrat, B., et al., 1995. Isolation and structure of the endogenous agonist of opioid receptor-like ORL1 receptor. Nature. 377, 532-5.

Miserez, B., De Block, J., Cortvrindt, R., Van Marck, E., De Potter, W.P., 1992. Preparation of noradrenaline-storing organelles from bovine sympathetic ganglia: biochemical and morphological evaluation of partly purified large dense cored vesicles. Neurochem Int. 20, 577-82.

Miyata, A., Arimura, A., Dahl, R.R., Minamino, N., Uehara, A., Jiang, L., Culler, M.D., Coy, D.H., 1989. Isolation of a novel 38 residue-hypothalamic polypeptide which stimulates adenylate cyclase in pituitary cells. Biochem Biophys Res Commun. 164, 567-74.

Moller, K., Zhang, Y.Z., Hakanson, R., Luts, A., Sjolund, B., Uddman, R., Sundler, F., 1993. Pituitary adenylate cyclase activating peptide is a sensory neuropeptide: immunocytochemical and immunochemical evidence. Neuroscience. 57, 725-32.

Mollereau, C., Parmentier, M., Mailleux, P., Butour, J.L., Moisand, C., Chalon, P., Caput, D., Vassart, G., Meunier, J.C., 1994. ORL1, a novel member of the opioid receptor family. Cloning, functional expression and localization. FEBS Lett. 341, 33-8.

Mollereau, C., Mouledous, L., 2000. Tissue distribution of the opioid receptor-like (ORL1) receptor. Peptides. 21, 907-17.

Mori, T., Kawashima, T., Beppu, Y., Takagi, K., 1994. Histamine release induced by pituitary adenylate cyclase activating polypeptide from rat peritoneal mast cells. Arzneimittelforschung. 44, 1044-6. 
Mork, H., Hommel, K., Uddman, R., Edvinsson, L., Jensen, R., 2002. Does nociceptin play a role in pain disorders in man? Peptides. 23, 1581-7.

Moskowitz, M.A., 1993. Neurogenic inflammation in the pathophysiology and treatment of migraine. Neurology. 43, S16-20.

Moulton, E.A., Schmahmann, J.D., Becerra, L., Borsook, D., 2010. The cerebellum and pain: passive integrator or active participator? Brain Res Rev. 65, 14-27.

Mulder, H., Uddman, R., Moller, K., Zhang, Y.Z., Ekblad, E., Alumets, J., Sundler, F., 1994. Pituitary adenylate cyclase activating polypeptide expression in sensory neurons. Neuroscience. 63, 307-12.

Mulderry, P.K., Ghatei, M.A., Spokes, R.A., Jones, P.M., Pierson, A.M., Hamid, Q.A., Kanse, S., Amara, S.G., Burrin, J.M., Legon, S., et al., 1988. Differential expression of alpha-CGRP and beta-CGRP by primary sensory neurons and enteric autonomic neurons of the rat. Neuroscience. 25, 195-205.

Munoz, M., Covenas, R., 2014. Involvement of substance P and the NK-1 receptor in human pathology. Amino Acids. 46, 1727-50.

Nakano, T., Shimomura, T., Takahashi, K., Ikawa, S., 1993. Platelet substance P and 5hydroxytryptamine in migraine and tension-type headache. Headache. 33, 528-32.

Nambu, T., Sakurai, T., Mizukami, K., Hosoya, Y., Yanagisawa, M., Goto, K., 1999. Distribution of orexin neurons in the adult rat brain. Brain Res. 827, 243-60.

Negro, A., Lionetto, L., Simmaco, M., Martelletti, P., 2012. CGRP receptor antagonists: an expanding drug class for acute migraine? Expert Opin Investig Drugs. 21, 807-18.

Nemeth, J., Reglodi, D., Pozsgai, G., Szabo, A., Elekes, K., Pinter, E., Szolcsanyi, J., Helyes, Z., 2006. Effect of pituitary adenylate cyclase activating polypeptide-38 on sensory neuropeptide release and neurogenic inflammation in rats and mice. Neuroscience. $143,223-30$.

Nicolodi, M., Del Bianco, E., 1990. Sensory neuropeptides (substance P, calcitonin generelated peptide) and vasoactive intestinal polypeptide in human saliva: their pattern in migraine and cluster headache. Cephalalgia. 10, 39-50.

Noseda, R., Jakubowski, M., Kainz, V., Borsook, D., Burstein, R., 2011. Cortical projections of functionally identified thalamic trigeminovascular neurons: implications for migraine headache and its associated symptoms. J Neurosci. 31, 14204-17.

Obermann, M., Yoon, M.S., Dommes, P., Kuznetsova, J., Maschke, M., Weimar, C., Limmroth, V., Diener, H.C., Katsarava, Z., 2007. Prevalence of trigeminal autonomic symptoms in migraine: a population-based study. Cephalalgia. 27, 504-9.

Odum, L., Petersen, L.J., Skov, P.S., Ebskov, L.B., 1998. Pituitary adenylate cyclase activating polypeptide (PACAP) is localized in human dermal neurons and causes histamine release from skin mast cells. Inflamm Res. 47, 488-92.

Olesen, J., Diener, H.C., Husstedt, I.W., Goadsby, P.J., Hall, D., Meier, U., Pollentier, S., Lesko, L.M., Group, B.B.C.P.o.C.S., 2004. Calcitonin gene-related peptide receptor antagonist BIBN 4096 BS for the acute treatment of migraine. N Engl J Med. 350, 1104-10.

Olias, G., Viollet, C., Kusserow, H., Epelbaum, J., Meyerhof, W., 2004. Regulation and function of somatostatin receptors. J Neurochem. 89, 1057-91.

Palkovits, M., Somogyvari-Vigh, A., Arimura, A., 1995. Concentrations of pituitary adenylate cyclase activating polypeptide (PACAP) in human brain nuclei. Brain Res. 699, 11620.

Patel, Y.C., O'Neil, W., 1988. Peptides derived from cleavage of prosomatostatin at carboxyland amino-terminal segments. Characterization of tissue and secreted forms in the rat. J Biol Chem. 263, 745-51. 
Pearson, J.C., Jennes, L., 1988. Localization of serotonin- and substance P-like immunofluorescence in the caudal spinal trigeminal nucleus of the rat. Neurosci Lett. $88,151-6$.

Pettersson, L.M., Heine, T., Verge, V.M., Sundler, F., Danielsen, N., 2004. PACAP mRNA is expressed in rat spinal cord neurons. J Comp Neurol. 471, 85-96.

Peyron, C., Tighe, D.K., van den Pol, A.N., de Lecea, L., Heller, H.C., Sutcliffe, J.G., Kilduff, T.S., 1998. Neurons containing hypocretin (orexin) project to multiple neuronal systems. J Neurosci. 18, 9996-10015.

Pietrobon, D., Moskowitz, M.A., 2013. Pathophysiology of migraine. Annu Rev Physiol. 75, 365-91.

Raddant, A.C., Russo, A.F., 2011. Calcitonin gene-related peptide in migraine: intersection of peripheral inflammation and central modulation. Expert Rev Mol Med. 13, e36.

Rahmann, A., Wienecke, T., Hansen, J.M., Fahrenkrug, J., Olesen, J., Ashina, M., 2008. Vasoactive intestinal peptide causes marked cephalic vasodilation, but does not induce migraine. Cephalalgia. 28, 226-36.

Rasmussen, B.K., Jensen, R., Schroll, M., Olesen, J., 1991. Epidemiology of headache in a general population--a prevalence study. J Clin Epidemiol. 44, 1147-57.

Reinscheid, R.K., Nothacker, H., Civelli, O., 2000. The orphanin FQ/nociceptin gene: structure, tissue distribution of expression and functional implications obtained from knockout mice. Peptides. 21, 901-6.

Russell, F.A., King, R., Smillie, S.J., Kodji, X., Brain, S.D., 2014. Calcitonin gene-related peptide: physiology and pathophysiology. Physiol Rev. 94, 1099-142.

Said, S.I., Mutt, V., 1970. Potent peripheral and splanchnic vasodilator peptide from normal gut. Nature. 225, 863-4.

Said, S.I., 1984. Vasoactive intestinal polypeptide (VIP): current status. Peptides. 5, 143-50.

Sakurai, T., Amemiya, A., Ishii, M., Matsuzaki, I., Chemelli, R.M., Tanaka, H., Williams, S.C., Richardson, J.A., Kozlowski, G.P., Wilson, S., Arch, J.R., Buckingham, R.E., Haynes, A.C., Carr, S.A., Annan, R.S., McNulty, D.E., Liu, W.S., Terrett, J.A., Elshourbagy, N.A., Bergsma, D.J., Yanagisawa, M., 1998. Orexins and orexin receptors: a family of hypothalamic neuropeptides and $\mathrm{G}$ protein-coupled receptors that regulate feeding behavior. Cell. 92, 573-85.

Sakurai, T., 2005. Reverse pharmacology of orexin: from an orphan GPCR to integrative physiology. Regul Pept. 126, 3-10.

Sakurai, T., 2007. The neural circuit of orexin (hypocretin): maintaining sleep and wakefulness. Nat Rev Neurosci. 8, 171-81.

Sandor, K., Bolcskei, K., McDougall, J.J., Schuelert, N., Reglodi, D., Elekes, K., Petho, G., Pinter, E., Szolcsanyi, J., Helyes, Z., 2009. Divergent peripheral effects of pituitary adenylate cyclase-activating polypeptide- 38 on nociception in rats and mice. Pain. $141,143-50$.

Sarchielli, P., Alberti, A., Codini, M., Floridi, A., Gallai, V., 2000. Nitric oxide metabolites, prostaglandins and trigeminal vasoactive peptides in internal jugular vein blood during spontaneous migraine attacks. Cephalalgia. 20, 907-18.

Sarchielli, P., Alberti, A., Candeliere, A., Floridi, A., Capocchi, G., Calabresi, P., 2006a. Glial cell line-derived neurotrophic factor and somatostatin levels in cerebrospinal fluid of patients affected by chronic migraine and fibromyalgia. Cephalalgia. 26, 409-15.

Sarchielli, P., Pini, L.A., Zanchin, G., Alberti, A., Maggioni, F., Rossi, C., Floridi, A., Calabresi, P., 2006b. Clinical-biochemical correlates of migraine attacks in rizatriptan responders and non-responders. Cephalalgia. 26, 257-65. 
Sarchielli, P., Pini, L.A., Coppola, F., Rossi, C., Baldi, A., Mancini, M.L., Calabresi, P., 2007. Endocannabinoids in chronic migraine: CSF findings suggest a system failure. Neuropsychopharmacology. 32, 1384-90.

Sarchielli, P., Rainero, I., Coppola, F., Rossi, C., Mancini, M., Pinessi, L., Calabresi, P., 2008. Involvement of corticotrophin-releasing factor and orexin-A in chronic migraine and medication-overuse headache: findings from cerebrospinal fluid. Cephalalgia. 28, 71422.

Saria, A., 1999. The tachykinin NK1 receptor in the brain: pharmacology and putative functions. Eur J Pharmacol. 375, 51-60.

Schytz, H.W., Birk, S., Wienecke, T., Kruuse, C., Olesen, J., Ashina, M., 2009. PACAP38 induces migraine-like attacks in patients with migraine without aura. Brain. 132, 1625.

Schytz, H.W., 2010. Investigation of carbachol and PACAP38 in a human model of migraine. Dan Med Bull. 57, B4223.

Schytz, H.W., Olesen, J., Ashina, M., 2010. The PACAP receptor: a novel target for migraine treatment. Neurotherapeutics. 7, 191-6.

Smitherman, T.A., Burch, R., Sheikh, H., Loder, E., 2013. The prevalence, impact, and treatment of migraine and severe headaches in the United States: a review of statistics from national surveillance studies. Headache. 53, 427-36.

Soll, R., Beck-Sickinger, A.G., 2000. On the synthesis of orexin A: a novel one-step procedure to obtain peptides with two intramolecular disulphide bonds. J Pept Sci. 6, 387-97.

Steiner, T.J., Gururaj, G., Andree, C., Katsarava, Z., Ayzenberg, I., Yu, S.Y., Al Jumah, M., Tekle-Haimanot, R., Birbeck, G.L., Herekar, A., Linde, M., Mbewe, E., Manandhar, K., Risal, A., Jensen, R., Queiroz, L.P., Scher, A.I., Wang, S.J., Stovner, L.J., 2014. Diagnosis, prevalence estimation and burden measurement in population surveys of headache: presenting the HARDSHIP questionnaire. J Headache Pain. 15, 3.

Strassman, A.M., Raymond, S.A., Burstein, R., 1996. Sensitization of meningeal sensory neurons and the origin of headaches. Nature. 384, 560-4.

Syed, A.U., Koide, M., Braas, K.M., May, V., Wellman, G.C., 2012. Pituitary adenylate cyclase-activating polypeptide (PACAP) potently dilates middle meningeal arteries: implications for migraine. J Mol Neurosci. 48, 574-83.

Tajti, J., Uddman, R., Moller, S., Sundler, F., Edvinsson, L., 1999. Messenger molecules and receptor mRNA in the human trigeminal ganglion. J Auton Nerv Syst. 76, 176-83.

Tajti, J., Uddman, R., Edvinsson, L., 2001. Neuropeptide localization in the "migraine generator" region of the human brainstem. Cephalalgia. 21, 96-101.

Tajti, J., Pardutz, A., Vamos, E., Tuka, B., Kuris, A., Bohar, Z., Fejes, A., Toldi, J., Vecsei, L., 2011. Migraine is a neuronal disease. J Neural Transm. 118, 511-24.

Tajti, J., Szok, D., Pardutz, A., Tuka, B., Csati, A., Kuris, A., Toldi, J., Vecsei, L., 2012. Where does a migraine attack originate? In the brainstem. J Neural Transm. 119, 55768.

Terenghi, G., Polak, J.M., Ghatei, M.A., Mulderry, P.K., Butler, J.M., Unger, W.G., Bloom, S.R., 1985. Distribution and origin of calcitonin gene-related peptide (CGRP) immunoreactivity in the sensory innervation of the mammalian eye. J Comp Neurol. 233, 506-16.

Tfelt-Hansen, P.C., Pihl, T., Hougaard, A., Mitsikostas, D.D., 2014. Drugs targeting 5hydroxytryptamine receptors in acute treatments of migraine attacks. A review of new drugs and new administration forms of established drugs. Expert Opin Investig Drugs. $23,375-85$. 
Thalakoti, S., Patil, V.V., Damodaram, S., Vause, C.V., Langford, L.E., Freeman, S.E., Durham, P.L., 2007. Neuron-glia signaling in trigeminal ganglion: implications for migraine pathology. Headache. 47, 1008-23; discussion 24-5.

Tippins, J.R., Di Marzo, V., Panico, M., Morris, H.R., MacIntyre, I., 1986. Investigation of the structure/activity relationship of human calcitonin gene-related peptide (CGRP). Biochem Biophys Res Commun. 134, 1306-11.

Trivedi, P., Yu, H., MacNeil, D.J., Van der Ploeg, L.H., Guan, X.M., 1998. Distribution of orexin receptor mRNA in the rat brain. FEBS Lett. 438, 71-5.

Tuboly, G., Vecsei, L., 2013. Somatostatin and cognitive function in neurodegenerative disorders. Mini Rev Med Chem. 13, 34-46.

Tuka, B., Helyes, Z., Markovics, A., Bagoly, T., Nemeth, J., Mark, L., Brubel, R., Reglodi, D., Pardutz, A., Szolcsanyi, J., Vecsei, L., Tajti, J., 2012. Peripheral and central alterations of pituitary adenylate cyclase activating polypeptide-like immunoreactivity in the rat in response to activation of the trigeminovascular system. Peptides. 33, 30716.

Tuka, B., Helyes, Z., Markovics, A., Bagoly, T., Szolcsanyi, J., Szabo, N., Toth, E., Kincses, Z.T., Vecsei, L., Tajti, J., 2013. Alterations in PACAP-38-like immunoreactivity in the plasma during ictal and interictal periods of migraine patients. Cephalalgia. 33, 1085-95.

Tvedskov, J.F., Lipka, K., Ashina, M., Iversen, H.K., Schifter, S., Olesen, J., 2005. No increase of calcitonin gene-related peptide in jugular blood during migraine. Ann Neurol. 58, 561-8.

Uddman, R., Tajti, J., Moller, S., Sundler, F., Edvinsson, L., 1999. Neuronal messengers and peptide receptors in the human sphenopalatine and otic ganglia. Brain Res. 826, 193-9.

Uddman, R., Tajti, J., Hou, M., Sundler, F., Edvinsson, L., 2002. Neuropeptide expression in the human trigeminal nucleus caudalis and in the cervical spinal cord $\mathrm{C} 1$ and $\mathrm{C} 2$. Cephalalgia. 22, 112-6.

Valenzuela, R.F., Donoso, M.V., Mellado, P.A., Huidobro-Toro, J.P., 2000. Migraine, but not subarachnoid hemorrhage, is associated with differentially increased NPY-like immunoreactivity in the CSF. J Neurol Sci. 173, 140-6.

Vaudry, D., Falluel-Morel, A., Bourgault, S., Basille, M., Burel, D., Wurtz, O., Fournier, A., Chow, B.K., Hashimoto, H., Galas, L., Vaudry, H., 2009. Pituitary adenylate cyclaseactivating polypeptide and its receptors: 20 years after the discovery. Pharmacol Rev. 61, 283-357.

Vause, C.V., Durham, P.L., 2010. Calcitonin gene-related peptide differentially regulates gene and protein expression in trigeminal glia cells: findings from array analysis. Neurosci Lett. 473, 163-7.

Vecsei, L., Widerlov, E., 1988. Brain and CSF somatostatin concentrations in patients with psychiatric or neurological illness. An overview. Acta Psychiatr Scand. 78, 657-67.

Vecsei, L., Widerlov, E., Ekman, R., Kovacs, K., Jelencsik, I., Bozsik, G., Kapocs, G., 1992. Suboccipital cerebrospinal fluid and plasma concentrations of somatostatin, neuropeptide $\mathrm{Y}$ and beta-endorphin in patients with common migraine. Neuropeptides. 22, 111-6.

Vecsei, L., Tuka, B., Tajti, J., 2014. Role of PACAP in migraine headaches. Brain. 137, 6501.

Vecsei, L., Szok, D., Csati, A., Tajti, J., 2015. CGRP antagonists and antibodies for the treatment of migraine. Expert Opin Investig Drugs. 24, 31-41.

Vollbracht, S., Rapoport, A.M., 2013. The pipeline in headache therapy. CNS Drugs. 27, 71729. 
Vollbracht, S., Rapoport, A.M., 2014. New treatments for headache. Neurol Sci. 35 Suppl 1, 89-97.

Vos, T., Flaxman, A.D., Naghavi, M., Lozano, R., Michaud, C., Ezzati, M., Shibuya, K., Salomon, J.A., Abdalla, S., Aboyans, V., Abraham, J., Ackerman, I., Aggarwal, R., Ahn, S.Y., Ali, M.K., Alvarado, M., Anderson, H.R., Anderson, L.M., Andrews, K.G., Atkinson, C., Baddour, L.M., Bahalim, A.N., Barker-Collo, S., Barrero, L.H., Bartels, D.H., Basanez, M.G., Baxter, A., Bell, M.L., Benjamin, E.J., Bennett, D., Bernabe, E., Bhalla, K., Bhandari, B., Bikbov, B., Bin Abdulhak, A., Birbeck, G., Black, J.A., Blencowe, H., Blore, J.D., Blyth, F., Bolliger, I., Bonaventure, A., Boufous, S., Bourne, R., Boussinesq, M., Braithwaite, T., Brayne, C., Bridgett, L., Brooker, S., Brooks, P., Brugha, T.S., Bryan-Hancock, C., Bucello, C., Buchbinder, R., Buckle, G., Budke, C.M., Burch, M., Burney, P., Burstein, R., Calabria, B., Campbell, B., Canter, C.E., Carabin, H., Carapetis, J., Carmona, L., Cella, C., Charlson, F., Chen, H., Cheng, A.T., Chou, D., Chugh, S.S., Coffeng, L.E., Colan, S.D., Colquhoun, S., Colson, K.E., Condon, J., Connor, M.D., Cooper, L.T., Corriere, M., Cortinovis, M., de Vaccaro, K.C., Couser, W., Cowie, B.C., Criqui, M.H., Cross, M., Dabhadkar, K.C., Dahiya, M., Dahodwala, N., Damsere-Derry, J., Danaei, G., Davis, A., De Leo, D., Degenhardt, L., Dellavalle, R., Delossantos, A., Denenberg, J., Derrett, S., Des Jarlais, D.C., Dharmaratne, S.D., Dherani, M., Diaz-Torne, C., Dolk, H., Dorsey, E.R., Driscoll, T., Duber, H., Ebel, B., Edmond, K., Elbaz, A., Ali, S.E., Erskine, H., Erwin, P.J., Espindola, P., Ewoigbokhan, S.E., Farzadfar, F., Feigin, V., Felson, D.T., Ferrari, A., Ferri, C.P., Fevre, E.M., Finucane, M.M., Flaxman, S., Flood, L., Foreman, K., Forouzanfar, M.H., Fowkes, F.G., Franklin, R., Fransen, M., Freeman, M.K., Gabbe, B.J., Gabriel, S.E., Gakidou, E., Ganatra, H.A., Garcia, B., Gaspari, F., Gillum, R.F., Gmel, G., Gosselin, R., Grainger, R., Groeger, J., Guillemin, F., Gunnell, D., Gupta, R., Haagsma, J., Hagan, H., Halasa, Y.A., Hall, W., Haring, D., Haro, J.M., Harrison, J.E., Havmoeller, R., Hay, R.J., Higashi, H., Hill, C., Hoen, B., Hoffman, H., Hotez, P.J., Hoy, D., Huang, J.J., Ibeanusi, S.E., Jacobsen, K.H., James, S.L., Jarvis, D., Jasrasaria, R., Jayaraman, S., Johns, N., Jonas, J.B., Karthikeyan, G., Kassebaum, N., Kawakami, N., Keren, A., Khoo, J.P., King, C.H., Knowlton, L.M., Kobusingye, O., Koranteng, A., Krishnamurthi, R., Lalloo, R., Laslett, L.L., Lathlean, T., Leasher, J.L., Lee, Y.Y., Leigh, J., Lim, S.S., Limb, E., Lin, J.K., Lipnick, M., Lipshultz, S.E., Liu, W., Loane, M., Ohno, S.L., Lyons, R., Ma, J., Mabweijano, J., MacIntyre, M.F., Malekzadeh, R., Mallinger, L., Manivannan, S., Marcenes, W., March, L., Margolis, D.J., Marks, G.B., Marks, R., Matsumori, A., Matzopoulos, R., Mayosi, B.M., McAnulty, J.H., McDermott, M.M., McGill, N., McGrath, J., Medina-Mora, M.E., Meltzer, M., Mensah, G.A., Merriman, T.R., Meyer, A.C., Miglioli, V., Miller, M., Miller, T.R., Mitchell, P.B., Mocumbi, A.O., Moffitt, T.E., Mokdad, A.A., Monasta, L., Montico, M., Moradi-Lakeh, M., Moran, A., Morawska, L., Mori, R., Murdoch, M.E., Mwaniki, M.K., Naidoo, K., Nair, M.N., Naldi, L., Narayan, K.M., Nelson, P.K., Nelson, R.G., Nevitt, M.C., Newton, C.R., Nolte, S., Norman, P., Norman, R., O'Donnell, M., O'Hanlon, S., Olives, C., Omer, S.B., Ortblad, K., Osborne, R., Ozgediz, D., Page, A., Pahari, B., Pandian, J.D., Rivero, A.P., Patten, S.B., Pearce, N., Padilla, R.P., Perez-Ruiz, F., Perico, N., Pesudovs, K., Phillips, D., Phillips, M.R., Pierce, K., Pion, S., Polanczyk, G.V., Polinder, S., Pope, C.A., 3rd, Popova, S., Porrini, E., Pourmalek, F., Prince, M., Pullan, R.L., Ramaiah, K.D., Ranganathan, D., Razavi, H., Regan, M., Rehm, J.T., Rein, D.B., Remuzzi, G., Richardson, K., Rivara, F.P., Roberts, T., Robinson, C., De Leon, F.R., Ronfani, L., Room, R., Rosenfeld, L.C., Rushton, L., Sacco, R.L., Saha, S., Sampson, U., Sanchez-Riera, L., Sanman, E., Schwebel, D.C., Scott, J.G., Segui-Gomez, M., Shahraz, S., Shepard, D.S., Shin, H., 
Shivakoti, R., Singh, D., Singh, G.M., Singh, J.A., Singleton, J., Sleet, D.A., Sliwa, K., Smith, E., Smith, J.L., Stapelberg, N.J., Steer, A., Steiner, T., Stolk, W.A., Stovner, L.J., Sudfeld, C., Syed, S., Tamburlini, G., Tavakkoli, M., Taylor, H.R., Taylor, J.A., Taylor, W.J., Thomas, B., Thomson, W.M., Thurston, G.D., Tleyjeh, I.M., Tonelli, M., Towbin, J.A., Truelsen, T., Tsilimbaris, M.K., Ubeda, C., Undurraga, E.A., van der Werf, M.J., van Os, J., Vavilala, M.S., Venketasubramanian, N., Wang, M., Wang, W., Watt, K., Weatherall, D.J., Weinstock, M.A., Weintraub, R., Weisskopf, M.G., Weissman, M.M., White, R.A., Whiteford, H., Wiersma, S.T., Wilkinson, J.D., Williams, H.C., Williams, S.R., Witt, E., Wolfe, F., Woolf, A.D., Wulf, S., Yeh, P.H., Zaidi, A.K., Zheng, Z.J., Zonies, D., Lopez, A.D., Murray, C.J., AlMazroa, M.A., Memish, Z.A., 2012. Years lived with disability (YLDs) for 1160 sequelae of 289 diseases and injuries 1990-2010: a systematic analysis for the Global Burden of Disease Study 2010. Lancet. 380, 2163-96.

Weiller, C., May, A., Limmroth, V., Juptner, M., Kaube, H., Schayck, R.V., Coenen, H.H., Diener, H.C., 1995. Brain stem activation in spontaneous human migraine attacks. Nat Med. 1, 658-60.

Zagami, A.S., Goadsby, P.J., Edvinsson, L., 1990. Stimulation of the superior sagittal sinus in the cat causes release of vasoactive peptides. Neuropeptides. 16, 69-75.

Zagami, A.S., Edvinsson, L., Hoskin, K.L., Goadsby, P.J., 1995. Stimulation of the superior sagittal sinus causes extracranial release of PACAP. Cephalalgia 15, 109. 